\title{
A New Discussion on the Significance of Calligraphy History of Wang Zhu
}

\author{
Jie $\mathrm{Li}^{1}$ \\ ${ }^{1}$ CAPITAL NORMAL UNIVERSITY, Beijing, 100000 \\ hunter2011@foxmail.com
}

Keywords: Calligraphy circles of in early Song dynasty, Wang Zhu, Courtyard body, Chunhua Ge tie

\begin{abstract}
The influential calligraphers at the beginning of Song Dynasty are very few. The emperorsin early Song dynasty knew that artistic heights and deep connotation of calligraphy of Two Wangs, especially the calligraphy of Wang Xizhi. The most prominent phenomenon in the calligraphy history in the early Song dynasty is the appointment of Wang Zhu as the Imperial Academy Shishu by Song Taizong. With its excellent calligraphy ability, Wang Zhu made outstanding contribution to early Song Dynasty calligraphy and had profound influences on after time. However, due to the disadvantages of courtyard bodycalligraphy and the faults ofinscribedChunhua Ge tie, the evaluation of Wang Zhu is not unfair. Further studies are necessary to evaluate the significance of calligraphy history of Wang Zhu.
\end{abstract}

\section{Introduction}

At the beginning of Song Dynasty, calligraphy arts fort was greatly damaged in the War in the late Tang and Five Dynasties. The influential calligraphers at the beginning of Song Dynasty are very few. However, "calligraphy" is an important one of the "six skills". It has the function of carrying the spread of Confucian classics and beauty education. It has been attached great importance to the early Song Dynasty emperor.

Faced with the weakness of Song Dynasty calligraphy, the calligraphy circle must establish unified regulations and standards to follow as soon as possible. The moral function and aesthetic function are unified as the standard of the Confucian literature and art, which is the standard of choosing the object of study. Then, whose calligraphy work is "good and beautiful" in thecalligraphy history?Tang Taizong Li Shimin first cleared to the "perfect" standard to examine evaluation calligraphers and considered Wang Xizhi calligraphy as the highest model identification to appreciate and learn. At the beginning of the Song Dynasty, the emperor know to Wang on behalf of the two kings of the calligraphy art and its "perfect and not stimulated excitation", "be helpful to education, be helpful to human relations", so the esteem of Wang Xizhi calligraphy spare no effort. At the beginning of the Song Dynasty in the calligraphy history of the most prominent phenomenon is one of the Song Taizong appoint Wang Hanlin paternity books, presided over the Imperial Academy, to the king with the representative of the Academy of calligraphy popular in the Song Dynasty. He chaired the inscription "Chunhua Getie" calligraphy which made the calligraphy work of Two Wangsdiffused in the court and the commonalty, and finally establishedthat Wang Xizhiwasthe representative of the calligraphy orthodoxy.

\section{Evaluation of Wang Zhu's Calligraphy Level}

As the imperial academy Shishu, Wang Zhupresided over the Royal Academy.The greatest impact of Wang Zhu is the impact of the courtyard body of calligraphy.

Courtyard body of calligraphy originated in Tang Taizong Zunwang, appeared in the middle period of Tang Dynasty, due to appear in the Imperial Academy named, is produced in the process of the calligraphy of Wang Xizhi a genre of people to learn, the book winds neat beautiful, dignified and serious. Thus it may be known than Wang Zhu was good at line, cursive, fill permanent really grass. The calligraphy not only had the beautiful body of Wang Xizhi's calligraphy but also had the 
powerful characters of Wang Xizhi's calligraphy of the late Tang Dynasty Five Dynasties. Qing Dynasty Lvjian in the stone extraction series correction "recorded Wang Bong Taizong life Book Zhuan" money Zhongyi Shinto monument "." right money Baoshu tombstone, when in Luoyang, this extension, unknown stone surviving or not? Green Park was arranged one, about one thousand to six hundred or seven hundred words, but only half of the Seoul, very beautiful. Representative calligrapher is Zhenyuan period of Hanlin Bachelor Wu Tongwei, Wu Tongxuan brothers and Prime Minister Wang Xianjin. They took the holy, the book wind clear round like, six dynasties rhyme. Their people learn calligraphy academy, eventually formed the Academy of calligraphy. Because the Catholic "is Wang Shu words, Kebei font size staggered changes are not natural, gas, ink is luxury, plus by Tang Kai size neat, Wang running increasingly size convergence set, and" Lanting $\mathrm{Xu}$ "and other books of rubbings repeatedly by turning moment, compared with the original, more and more pales by comparison, so Wang body running in the Mid Tang Dynasty, after increasingly lack of glucosamine. Han Yu'sShigu song criticized the defects in the cloud" Xizhisushuchenzimei", which means that the calligraphy of Wang Xizhi sometimes lacked of power.

In the Five Dynasties, the courtyard body of calligraphywas more vulnerable. Known by the material, at the beginning of the Song Dynasty, Wang before, Academy of calligraphy circle Yi deportment, the word potential light weak, centralized professional book hand most of the Imperial Academy like this, not to mention other government departments and social writing level.

As the leader of the Shujishuguan and the most valuablecalligrapher in Song Taizong's eyes, he led the Imperial Academy of calligraphy, makingthe Five Dynasties and the early Song Dynasty's extravagant weak Book wind has been greatly improved. Whether it is written or carved, have made considerable progress. Wang Yan beauty, mellow, Qiu Jin's book wind recovers from the Jin and Tang Dynasties correct at the end of the Tang Dynasty and the Five Dynasties, to open a revival of the Song Dynasty calligraphy. Wang, after, Hanlin academy calligraphy gradually return Yazheng, book wind have much better, such as Xing Shouyuan, its "Beiyue an Tianyuan sage tablet" Dubai Li elegant, than at the beginning of the Song Dynasty, the Academy calligraphers a taste mellow have greatly improved. Another example Xuji book "Helan Yang Chi", "Yanqing Qizhen Temple stupa", is a powerful gas flow beauty. Visible, academician Shi Shu Wang with a Academy of calligraphy, the second peak in Wu Tong, Wu Tongxuan, alternative Academy of Wu Chengwei body of Book Wind's new representative, by the Northern Song Dynasty and the Southern Song Dynasty, Wang thou calligraphy become Imperial Academy model, much of the Imperial Academy of calligraphy officials favor, Wang books is also referred to as the "Wang", eventually song life never change. Wang books not only influences the Hanlin academy wind, also affects the society of calligraphy study and criticism of the standard, Huang, "epilogue Dongpo calligraphy Yuanjing tower after Fu" cloud: "this Suzi shock rating Dongpo and other lid by Academician Shi Shuzhi Shengmo scale, are you knowing the meaning of the law!" Although this is the language of anger, we could see that the grate social reputation and deep influence of Wang Zhu. Even his calligraphy became social learning calligraphy guide and the standard of criticism.

\section{Influence of Wang Zhu on Song Taizong's Calligraphy and Courtyard Body}

There is a historical paragraph cited very frequently in the literature of Song Dynasty, "leisure Taizong hearing, taste in reading the writing meaning, different fonts, Dong Zhen subtle. In order to make the taste of Wang Renrui shows the king with the Royal Zagreb, said: 'no good.' The study also Taizong frequently show the answer as before. RenRui, the reason, said: 'the emperor began to attack the book, or suddenly said, there will be no attention at all.' For a long time, it is a sign that says, 'work has come to also, and the non-minister can. The taste of authentic language and its prime minister are good to Gui Yi." Traces of Kai King in calligraphy, Song Chuzhi that Emperor Taizong in paternity books Wang, "Gui Yi", calligraphy has made great progress, Jiang Shao Yu of the Song Dynasty court "Seventeen volumes also said the subsequent emperor must fine brushwork, beyond the ancient world thinks with the Gui Yi, Wang Zhu and therefore more affected by Emperor Taizong's attention, later the emperor for the matter to the king with praise, in the king's 
Gui Yi, Emperor Taizong book learning to become more sophisticated and Taizong's influence to create a new situation," a long series of "volume 68 contained in the" Five Dynasties towards the body book, absolutely, this is as far as learning clock, king, Europe, Liu Yi. " Under the guidance of the king with the, Taizong's active promotion, at the beginning of the Song Dynasty, the book wind gradually return to orthodoxy, has laid a good foundation for the sustainable development of calligraphy in the early Song Dynasty.

Chunhua three years (AD 992), Taizong ordered Wang Zhu to select the famous book traces within the government to offer the hidden emperors and ministers to edit and publish ten large volumes of the official Cong posts "Chunhua Ge tie", "Taizong purchase of ancient and modern books and the king with resolution of coarse and fine as calligraphy copybook, the ten volumes."'In Chunhua, Cuba remains within the government as Bo, when the imperial Book King Zhao Shi Zhu posts are continued." At the beginning of the couch "Ge tie" advent Jerneh Tang with Li Tinggui ink Liu Cizhuang "after the village set - sequence old Tan post" evaluation said, "or seven or eight behavior a, or sixteen behavior a, all Ting Gui ink printing, the black, such as paint, in particular word Feng Yan. The eight law of the city of the city is high, and the king of the city is a fine man." The Ge tie "soon became a model of social learning calligraphy, Song poem:" heavy Brew House mash, hook officer posts, along with Weng smile into ruin. What night on the green album, a Penglai month window." Sun Kuang "painting and calligraphy postscript postscript - Li Honglu Chunhua residual Esther" also said "no Fateh lately, steep Er, mortal chimer Mingji club, the physique also mildly, and Soji slightly larger or tiny get Biyi, Anderson does not make a person envy."'Chunhua Ge tie publishing is complete, caused the widespread concern.It is ancient government for the first time on a large scale will be famous ancient Mingji popularity is transmitted to the society and promote the calligraphy of multiple health development."Chunhua Ge tie" ten volumes, the calligraphy of the two Wangs accounted for five volumes, post number accounted for more than half the entire post number, the Ge tie "eventually replaced the domination of the Catholic order", established by Wang Xizhi is representative of the calligraphy of the two Wangs orthodoxy, thus making the king with officer posts published moment and in the history of calligraphy occupy the important position. Since then, "Chunhua Ge tie" criticism, textual research, the author of the article works continue to emerge, "Ge tie" of various derivatives widely spreaded. The emperor Qian Long "Emperor Xuan Chunhua" remember commenting: "words will quote Zhao song of Judah to close, and song posts in Chunhua for the United States will." It is even the main monument of Kang Youwei also in his book extended double album "six volumes said:" posts to the king with the Ge tie "as the originator, better the rare, although this depends on the style of the Jin Dynasty and comfort to win without also". Although the inscription of Ge tie was not very perfect, the founded exploits would not sink into oblivion.

\section{Conclusion}

The evaluation of Wang Zhu should not only stay in the negative effects of the courtyard body and the inscription faults of "Chunhua Ge tie". We should combine the specific historical timeand cultural environment to precisely and fairly asses the real role of Wang Zhu. We should not rely on later generations all kinds of comments.And the importance of the emperor and even the weak king of rhyme books later Huang Tingjian evaluation "spent" and less "Xiongci" and "mellow", and I do not know the body for the imperial Shi book, at that time, the ruling and opposition parties cannot, and the king to his solid Two Wangs skills affect the emperor and the Imperial Academy at the beginning of the Song Dynasty books wind to a Kabuki operation officer's identity, the king has deserved to take seriously, worthy of the times of his calling, and later calligraphers calligraphy founded the higher peak is standing in the previous generation calligraphers of the shoulders and move on. The king in the emperor heart in the early Song Dynasty, there is a king in this water calligraphy calligrapher of the scarce. In a critical period of Song Dynasty calligraphy extravagant weak, Wang to his remarkable level of calligraphy in the early Song Dynasty, especially pours fresh blood into the Academy of calligraphy, promote the imperial calligraphy level increased and the early Song Dynasty calligraphy revitalization."Chunhua Getie" publication established the 
calligraphy of Two Wangs supreme status and made the spread of classical calligraphymore popular. It promoted the representative Song Dynasty calligraphy formation. With the model calligraphycontinued to be published over and over again, "Chunhua Getie" have formed the study of calligraphy book which profoundly influenced the after time.

\section{References}

[1] L.J. Fang, Corrections to the Jinshi Succinct, Cathay Bookshop, 1985.

[2] Literary Sketches in Song and Yuan Dynasty, Shanghai Ancient Books Publishing Company, 2001

[3] G. Zhao, Selected Essays of Calligraphy in History, Shanghai Book and Painting Press, 1979.

[4] Z.Y. Tao, Chinese calligraphy and painting, Chinese Calligraphy and Painting, 1993. 